
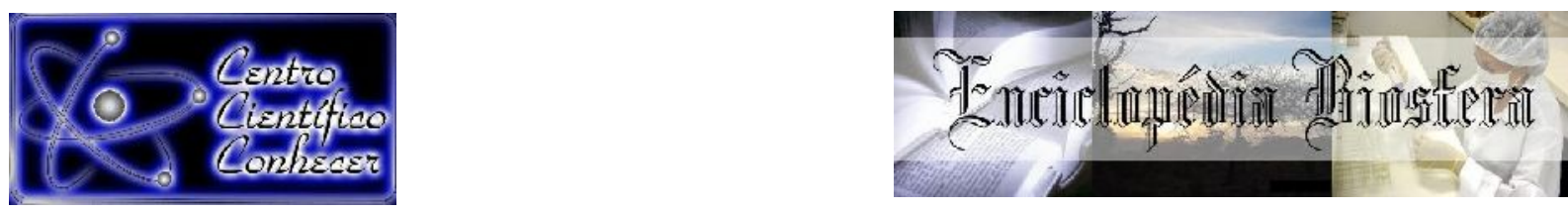

\title{
A RELAÇÃO PROFESSOR-ALUNO APLICADA AO CONTEXTO DA EDUCAÇÃO SUPERIOR
}

\begin{abstract}
Dalila Almeida Lima ${ }^{1}$; Ariel Eurides Stella
*Professor Associado II, Universidade Federal de Jataí - UFJ, Brasil, ariel.vet@gmail.com (corresponding author), 55-6436068223;

${ }^{1}$ Mestranda do Programa de Pós Graduação em Biociência Animal, Universidade Federal de Jataí - UFJ, Brazil, 55-6436068223;

Recebido em: 15/05/2020 - Aprovado em: 15/06/2020 - Publicado em: 30/06/2020 DOI: 10.18677/EnciBio_2020B48

RESUMO

A todo o momento as pessoas se conectam umas às outras através do diálogo, gestos e expressões corporais não verbais, que comunicam e possibilitam conviver em sociedade. Este processo de relacionamento e de interação, talvez, seja o que diferencia o homem das demais espécies animais, pois a partir da comunicação e afetividade as pessoas se conectam em comunidade e passam a integrar um contexto social que permite-se desenvolver atitudes e pensamentos para um evoluir constante. No ambiente universitário estas mesmas relações se desenrolam a cada segundo e a boa interação entre os professores e alunos em nível do ensino superior evidencia ser o modus operandis mais fidedigno para a construção e sedimentação do processo recíproco de ensino e aprendizagem. Muitos estudos de vários autores renomados corroboram com este conceito e através deste trabalho exploratório descritivo se propõe uma revisão sistematizada de teorias e da literatura, evidenciando os conceitos mais contundentes e cabais que projetam esta boa relação como fator primordial para a aproximação entre os sujeitos envolvidos, a fim de se conquistar sucesso no processo de formação pessoal e profissional dos alunos e, consequentemente, dos próprios seres humanos.
\end{abstract}

PALAVRAS-CHAVE: Aprendizado, Graduação, Universidade.

\section{THE PROFESSOR-STUDENT RELATIONSHIP APPLIED TO THE CONTEXT OF COLLEGE EDUCATION}

\begin{abstract}
At all times, people connect to each other through dialogue, gestures and non-verbal bodily expressions, which communicate and enable us to live in society. This process of relationship and interaction, perhaps, is what differentiates us from other animal species, because through communication and affection we connect to each other in community and we integrate a social context that allows us to develop attitudes and thoughts for a evolve steadily. In the university environment, these same relationships develop every second and the good interaction between teachers and students at the college education level shows evidences to be the modus operandis more reliable for the
\end{abstract}


construction and sedimentation of the reciprocal teaching and learning process. Many studies by several renowned authors corroborate this concept and, through this descriptive exploratory work, a systematic review of theories and literature is proposed, evidencing the most forceful and convincing concepts that project this good relationship as a primary factor for the approximation between the subjects involved, in order to achieve success in the process of personal and professional training of students and, consequently, of human beings themselves.

KEYWORDS:, Graduation, learning, University.

\section{INTRODUÇÃO}

A relação professor-aluno, em geral, sempre foi alvo de tensão. Tudo isto vem ocorrendo, desde que a escola se institucionalizou, com a antiga função de preparar trabalhadores submissos e passivos, através de uma abordagem centrada em uma concepção de aprendizagem mecânica, baseada na transmissão de conteúdos dogmatizados e descontextualizados. Neste sentido, pode-se inferir que apesar dos alunos apresentarem expectativas de apoio por parte dos professores, os elementos (comunicação, cumplicidade, satisfação, devoção e entender) que seriam muito importantes para a construção de uma relação positiva entre o professor e o aluno, encontram-se distantes das representações sociais dos mesmos (COSSO et al., 2018). Entretanto, a partir de novas metodologias de ensino disponíveis, pode-se e deve-se mudar esta concepção, para que a boa relação professor-aluno ocorra de forma favorável a todos os sujeitos envolvidos.

Para que esta interação propícia ocorra de fato, o professor como mediador deve criar oportunidades para conversas e bate-papos informais com os alunos, permitindo até mesmo a expressão de reclamações e críticas. Logo, o educador deve estar apto e ter a disposição de atender as solicitações dos alunos, dando condições para que eles tenham respostas as suas perguntas, aos seus questionamentos e as suas curiosidades. Na abordagem de Libâneo (1998), o mundo contemporâneo pede uma participação mais efetiva da escola como local transformador, inserida em seu contexto social, e o País deve valorizar a educação para que isso propicie educadores mais preparados, com mais cultura, flexíveis, e que objetivem a melhoria expressiva da convivência entre estes docentes e seus alunos. Afinal, ao se qualificar esta convivência, adquire-se, por pressuposto, o que se chama de um bom relacionamento entre as pessoas, sendo esta interação fundamental para o processo do ensino educativo. Além disso Silva (2014) menciona que é relevante a compreensão de que a postura ética está no interior de cada pessoa, ultrapassando para além do individual, ou seja, esta é social e alicerça valores morais de comportamentos que visam à transformação da sociedade e consequentemente do ambiente universitário.

Santos (2001) aponta que uma parcela substancial de pesquisas realizadas no ensino superior tem indicado a verdadeira importância da relação professor aluno e afirma que esta interação, dentro e fora da sala de aula, é o que verdadeiramente caracteriza um ensino de qualidade, o que acaba ajudando os estudantes a atingirem os seus objetivos de aprendizagem. Esta relação bem estabelecida e concretizada é que leva a formação de um ser cidadão mais preparado para enfrentar o mercado de trabalho, como também mais confiante para enfrentar desafios e dificuldades que surgem durante sua própria trajetória de vida. 
Ademais, de acordo com Buber (2006), a falta de diálogo é um dos principais fatores que contribuem para a falta de estímulos, pois, contrariamente ao que se imaginava, quando um aluno é ouvido, é que, de fato, acontece a troca de informações entre professor - aluno, demonstrando reciprocidade e levando ao consequente aprendizado. Além disto, é importante considerar que tem seu valor positivo, para a relação entre professor/aluno, o clima estabelecido pelo docente durante a relação empática com seus discípulos; sua capacidade de ouvir, refletir, discutir, o nível de compreensão dos mesmos e da criação das pontes entre o seu conhecimento e a contrapartida dos alunos. Sendo assim, a participação dos discentes nas aulas é de suma importância, pois expressarão seus conhecimentos, preocupações, interesses, desejos e vivências, podendo assim, contribuir de forma ativa e crítica na construção e reconstrução da cultura de movimento e do grupo em que vivem (GÓMEZ, 2000).

O mais importante para os alunos nessa relação, segundo Furlani (2004), é o contato com o professor e com a possibilidade de sentí-lo próximo, amigo, acessível e humano. Anastasiou e Alves (2004) apontam a necessidade de uma mudança na organização das aulas no ensino superior, ultrapassando a ação de "assistir aula" em direção ao fazer aulas, sempre caminhando no sentido da elaboração do conhecimento com a "realização de diversas operações mentais, num processo crescente de complexidade do pensamento".

O modo de agir do professor em sala de aula, mais do que suas características de personalidade, que colabora para uma adequada aprendizagem dos alunos, nesse contexto, entende-se que a qualidade de atuação da escola não pode exclusivamente depender somente da vontade de um ou outro professor. É importante e necessária a participação efetiva e conjunta da escola, junto da família, do aluno e profissionais ligados à educação, de forma que o professor também entenda que o aluno não é um sujeito somente receptor dos conhecimentos "depositados" (FREIRE, 1967).

Cosso et al., (2018) citam que a construção do conhecimento ocorre a partir de uma relação interpessoal entre professor-aluno, no qual o professor se apresenta como a figura central na mediação dos conteúdos que serão abordados, discutidos e apreendidos por todos os integrantes desse processo.

Os professores, portanto, devem se aproximar dos alunos, segundo Vygotsky (1997) e tornarem-se mediadores na construção de seus conhecimentos. Desta forma, os alunos passam de simples receptores de informações processadas, para autores e atores de sua própria aprendizagem, na busca pela construção de significados e não apenas da absorção de conceitos desconectados da realidade vigente. Entende-se, pois, que o saber da experiência com a docência está inserido ao próprio trabalho do professor, aos modos de seu proceder em sala de aula, em suas atitudes, na forma como ele é percebido, e como este se percebe na sociedade atual.

O saber da experiência docente está articulado a outros saberes, pois ele não dá suporte suficiente para atender as necessidades emergentes do contexto escolar. Nesta perspectiva, Pimenta e Anastasiou (2010) defendem que "não há modelos ou experiências a serem aplicadas. A experiência acumulada serve apenas de referência, nunca de padrão de ações com segurança de sucesso". Deve-se pensar a escola como um ambiente atrativo para professores, alunos e os profissionais nela atuantes, para que estes possam se sentir convidados a participar desta atmosfera de conhecimento que dia após dia é construída por professores e alunos, aproveitando o conhecimento prévio que é trazido por todos. Precisa-se que os docentes reinventem e reencantem a 
educação, tendo como foco uma visão educacional holística, usufruindo do conhecimento já construído e produzindo novas experiências no processo de ensinoaprendizagem dos educandos (ASSMANN, 2007).

O fato é que o mundo mudou e nas instituições de ensino superior, a relação professor e aluno foi ressignificada, colocando agora o estudante no centro do processo de aquisição do conhecimento, em uma espiral de interatividade e de troca de experiências de vida, o que faz toda a diferença em sua formação. Neste contexto e diante das experiências vividas em sala de aula e da necessidade de entender mais sobre esta relação professor aluno ambientada no ensino superior que foi elaborado este trabalho de pesquisa para identificar através de estudos e revisões teóricas e bibliográficas a influência da boa relação professor-aluno no ensino superior e suas melhorias para formação profissional dos alunos, enfatizando os principais teóricos e citando como eles definem esta relação no ensino universitário.

O método escolhido e, então, utilizado para a execução desta pesquisa foi o estudo exploratório com caráter explicativo por meio de uma revisão teórica e organizada da literatura e, também, de outras fontes de dados e informações disponíveis na atualidade.

Tratou-se, portanto, de uma pesquisa norteada a partir do levantamento bibliográfico, e de achados científicos em meios eletrônicos, de artigos, resenhas críticas e de legislações pertinentes, além de instruções técnicas e recomendações preconizadas tanto por órgãos governamentais quanto não governamentais publicados em um período pré-estabelecido.

A busca dos estudos ocorreu entre os meses de setembro e outubro do ano de 2018, por meio de consultas às bases de dados. Para tanto, foram utilizados o índex de pesquisas e compêndios das ciências da educação, a saber: Google Scholar, Scielo, e Portal de Periódicos da Coordenação de Aperfeiçoamento de Pessoal de Nível Superior (CAPES). Realizou-se um levantamento em anais de congresso e em periódicos das áreas da educação e em específicos aqueles com abordagem de nível superior/universitário. As palavras chave e descritores utilizados para identificar, nos meios eletrônicos, obras e autores que discorreram sobre o tema apresentado pelo estudo, foram: Boa relação, professor-aluno, ensino superior.

As buscas realizadas através das referidas bases de dados geraram resultados mais seletivos do que aqueles que aparecem em buscadores eletrônicos convencionais. Como critério de inclusão e exclusão do material utilizado para a pesquisa foram estabelecidos filtros para as buscas excluindo-se os conteúdos digitais publicados em blogs e sites convencionais e que, portanto, não possuíam evidências cientificas. A relevância de cada publicação, por sua vez, foi determinada por itens como a representatividade do autor, 0 ano de publicação e principalmente pela frequência de citações destes autores em outras pesquisas, pois foi levado em consideração o número de trabalhos acadêmicos referenciados em outros textos, onde através destes foram selecionados aqueles que tiveram maior importância para a comunidade científica.

A partir da relevância dos trabalhos publicados e que foram encontrados pelas pesquisas nas referidas bases de dados; foram analisados aqueles principais autores, com trabalhos mais representativos e maior influência para o universo educacional e científico; levando-se em consideração um determinado período cronológico, quando todas as fontes eletrônicas, literárias e bibliográficas que tratassem do objeto de 
pesquisa analisado foram estudadas e, consequentemente, citadas para a construção do referencial teórico e demais componentes da pesquisa final. Foram feitas buscas em diferentes bases de dados de todas as obras referentes ao tema: a boa relação professor aluno, principalmente aquelas interações interpessoais existentes e ambientadas no ensino superior. Os principais achados literários encontrados foram, então, organizados e analisados categoricamente. As informações extraídas serviram para a elaboração do texto científico final de maneira a destacar as principais circunstâncias e a salientar aquelas propostas consideradas concludentes; observandose, sempre, a temática e procurando-se alcançar os objetivos propostos pela pesquisa.

\section{REVISÃO TEÓRICA}

A educação superior, no Brasil, segue as determinações da Lei de Diretrizes e Bases da Educação (LDB), Lei n. 9.394/96, de 20 de dezembro de 1996. Esta mesma lei delega à União as competências para definir as normativas que orientarão o nível de ensino dito como universitário. Desta maneira, de acordo com a LDB, a educação superior tem como principal finalidade estimular a criação cultural, o desenvolvimento do espírito científico e o do pensamento reflexivo, incentivando-se, para isto, o trabalho de pesquisa e a investigação científica, com vistas ao desenvolvimento da ciência e da tecnologia e da criação e difusão da cultura, o que acabará proporcionando um melhor entendimento do homem e do meio em que este vive (BRASIL,1996).

A referida lei promove a descentralização e a autonomia para as escolas e universidades, além de instituir ordinariamente um processo regular de avaliação do ensino oferecido por tais instituições. Valoriza também o exercício do magistério. É nesse arcabouço de regras e normas orientadas pelo sistema educacional, via Lei $\mathrm{n}$. o 9394/96, que, no artigo 12, inciso I, no qual se prevê que "os estabelecimentos de ensino, respeitadas as normas comuns e as do sistema de ensino, terão a incumbência de elaborar e executar a proposta pedagógica". Nestes ambientes e contexto geral é que se estabelecem as relações existentes entre professor - aluno (BRASIL, 1996).

Relações interpessoais são interações humanas complexas e bastante profundas e que ocorrem permanentemente entre as pessoas através de comportamentos verbais e não-verbais, pensamentos, sentimentos, reações mentais e físico-corporais. Adicionalmente, segundo Tavares (1996), existe uma assimetria que sempre remete a não sobreposição desta relação interpessoal. Pois, por maior que seja o grau de reciprocidade relacional, os sujeitos da relação continuam sendo um ser uno, único e distinto.

Compreende-se então a relação professor-aluno na educação superior, como aquela que se constrói no cotidiano universitário e que permite perceber o perfil do "contrato didático". Esta combinação é definida por Brousseau (1998) como um contrato que se estabelece entre o professor e o aluno, com regras claras acerca do comportamento que se espera para ambos.

Esse conceito de contrato didático reafirma a concepção e o papel das instituições de educação superior como sendo instituições sociais que têm como responsabilidade a formação do sujeito, não exclusivamente por meio do ensino, pesquisa e extensão, mas também pela transmissão cultural. Isto vai ao encontro da principal finalidade da educação, dita como superior e expressa na Lei de Diretrizes e Bases da Educação, especialmente no Art. 43 (BRASIL, 1996). 
Ademais, segundo Jusviack (2008), para se estabelecer a relação professor $x$ aluno e para que essa relação tenha sentido é necessário à aprendizagem. Logo, para alcançar tal objetivo é indispensável, também, a presença de algumas condições elementares inseridas em um ambiente adequado, tais como: metodologia propícia, materiais, consideração de experiências anteriores, atenção, concentração, disciplina, entre outros. A relação com o saber na sala de aula mediante "uma verdadeira negociação do contrato didático", requer do professor a vontade e a capacidade de escutar os alunos, de ajudá-los a formular seu pensamento e de ouvir e se envolver com suas declarações (GIL, 2008).

Como visto, a relação professor-aluno se desenvolve a partir da realização de ações as quais devem ser mútuas e recíprocas; e que pensadas dentro de um espaço organizacional de aprendizagem, como a escola, devem, também, serem pautadas na interação face a face, na comunicação linear e no diálogo com intencionalidade de se contribuir e promover a troca de experiências que seja fortuita ao processo de ensino e aprendizagem, tendo sempre a ética como um princípio balizador dessa relação a qual deve estar diluída na estrutura curricular da própria escola, entendendo-se este currículo como "um espaço de cunho discursivo em que os sujeitos do processo de ensino, o professor e aluno, são diferenciadamente construídos como sujeitos individuais para se autorregularem, autodisciplinarem e refletirem sobre si mesmos como membros de uma comunidade/sociedade" (POPKEWITZ, 2001).

Para Cunha (2006) a relação professor-aluno se dá através da reciprocidade, pois o comportamento do professor influencia o comportamento do aluno e vice-versa. A produção do conhecimento é entendida como a atividade do professor que leva a ação, a reflexão crítica, a curiosidade, ao questionamento exigente, a inquietação e a incerteza. É o oposto da transmissão do conhecimento pronto e acabado. É a perspectiva de que ele possa ser criado e recriado pelos estudantes e pelos professores na sala de aula. Há uma expectativa nos resultados da relação professor e aluno em relação ao seu próprio desempenho, pois os professores participam de múltiplas interações sociais no dia a dia e precisam ajustar cotidianamente o trabalho a realidade imediata apresentada pela escola.

Para Silva (2005) essa relação é baseada em interesses e intenções, e tem como intuito principal o aprendizado, de onde acaba gerando a educação, esta que é uma das fontes mais importantes do desenvolvimento comportamental e agregação de valores de qualquer cidadão. Sendo assim o papel do professor é de facilitador da aprendizagem, não detentor de todo o saber, devendo estar aberto a novas experiências, a compreensão dos sentimentos e os problemas dos alunos, porquanto alunos aprendem muitas outras coisas além daquelas que os professores esperam que aprendam. Isto porque os professores também ensinam outras coisas além daquelas que se propõem a ensinar. Mas não pode ser esquecido que o professor também pode aprender com o aluno, que é possível haver uma troca de conhecimentos, uma vez que possuem saberes diferentes. Assim faz-se importante que a função do professor seja vista como o facilitador, buscando a compreensão comum no processo de construção do conhecimento compartilhado, que se dá somente pela interação.

Logo, pode-se entender claramente que a existência da afetividade se constitui como um fator preponderante e de extrema importância para o processo de desenvolvimento do próprio indivíduo e consequentemente na relação que o mesmo estabelece com o outro e a sociedade, pois é por meio desse outro que o sujeito poderá 
se entender e também se delimitar como pessoa humana, processo este que se encontra em estado de permanente construção. Nesse sentido, é essencial que o professor de Ensino Superior esteja envolvido em tal ciclo de conhecimento, e também, de crescimento pessoal/profissional, considerando a afetividade como parte necessária do desenvolvimento humano, buscando a formação integral dos estudantes universitários e uma vivência positiva do processo de ensino e aprendizagem (LEITE, 2006a). Além disso Silva (2019) cita que a afetividade deve ser vista como um fator fundamental na aprendizagem e no estabelecimento de elos sociais sólidos e maduros, não unicamente para o ensino básico, fundamental e médio, mas de muita relevância e urgência no Ensino Superior. A afetividade é quem direciona os atos, e talvez seja o elemento que mais influencia na formação do caráter.

Percebe-se que a afetividade faz parte do todo do indivíduo como uma fonte geradora de energia e uma força que o acompanha desde o nascimento até a morte. Portanto é também no Ensino Superior, tendo o professor como um aliado e mediador de conteúdos que são repassados através de um relacionamento de afetividade que o aluno, na sua passagem de jovem a vida adulta, terá na construção de uma boa relação afetiva adquirido mais confiança, segurança e equilíbrio, passando a ter interesse pela realidade e com isso a realizar com maior habilidade uma leitura do contexto no qual está inserido apresentando melhor compreensão e um melhor desenvolvimento intelectual (SILVA, 2019). Por isso, é importante que, na relação entre professor e aluno, sejam levados em consideração tanto os aspectos cognitivos quanto os aspectos afetivos desta relação. Piaget (1992), afirma ainda que o afeto demonstra ser uma importante energia para o desenvolvimento cognitivo, e que a afetividade influencia muito no conhecimento construído de forma essencial através da pulsação da vida e do esmero e busca pela excelência.

Desta maneira, é possível afirmar que será de responsabilidade do professor a perfeita articulação dos aspectos afetivos e cognitivos que se desenvolvem a partir das relações concebidas em sala de aula. Leite (2006a) afirma que em todas as principais decisões executadas na etapa de ensino assumida pelo professor, a afetividade sempre está presente: seja na escolha dos objetivos do ensino, ou no ponto de partida do processo de ensino aprendizagem; a afetividade também será encontrada na organização dos conteúdos, nos processos e atividades de ensino e nos procedimentos de avaliação, constituindo-se, desta forma, como aquele fator fundante das relações que se estabelecem entre os alunos e os conteúdos escolares ou acadêmicos, na mediação com o respectivo docente. Talvez seja o modo de agir do professor em sala de aula, mais do que as características de personalidade que colaboram para uma adequada aprendizagem dos alunos.

A relação entre as partes, que são integrantes deste processo exige uma interação elevada entre os mestres e seus discípulos com foco na construção do conhecimento. A comunicação clara, direta e sem ruídos emana como uma ferramenta que possa facilitar o alcance de tal objetivo. O cenário escolar, mesmo em seus diferentes níveis, deve oferecer ambientes propícios para que tais interações, e, comunicações existam de forma a possibilitar e concretizar o completo processo da obtenção da aprendizagem. Portanto, professores e alunos tornam-se corresponsáveis mútuos pelo sucesso da produção, construção e sedimentação do conhecimento popular e científico (BORDENAVE, 2006). 
O educador para pôr em prática o diálogo necessário para o entendimento entre as partes envolvidas, não deve colocar-se jamais na posição de detentor supremo do saber. Como pontuado por Meireles et al. (2017), o processo ensino-aprendizagem se dá em um contexto histórico-social e cultural que não pode ser desprezado, o que traz para o professor a responsabilidade de abrir e conduzir o diálogo de forma madura e democrática, respeitando a condição de sujeitos nos alunos e alçando o conhecimento à razão comunicativa. Portanto a formação educativa não se limitará ao escopo de uma razão instrumental, assaz técnica e alienante. Ao docente de ensino superior faz-se necessária uma interação com seus alunos que possibilite a formação de sujeitos que tenham consciência e discernimento acerca das peculiaridades do mundo. Priorizando a racionalidade comunicativa, o espaço acadêmico contribui para a formação de sujeitos autônomos, éticos, emancipados e responsáveis pela construção de uma nova sociedade em que a convivência harmoniosa tem lugar.

Adicionalmente, para Paulo Freire o diálogo é uma exigência existencial. Se ele é o encontro em que se solidarizam o refletir e o agir de seus sujeitos endereçados ao mundo a ser transformado e humanizado, não pode reduzir-se a um ato de depositar ideias de um sujeito no outro, nem tampouco tornar-se simples troca de ideias a serem consumidas pelos sujeitos envolvidos e permutantes (FREIRE, 2005).

Segundo Capitanio (2003) a comunicação ou diálogo é um processo em que uma pessoa emite uma mensagem para outra. Logo, a pessoa que envia, codifica os pensamentos em uma mensagem, e assim esta é canalizada geralmente por palavras para o receptor. O receptor decodifica a mensagem, pensa sobre e responde internamente. Portanto, para que a comunicação seja eficaz a mensagem deve ser obrigatoriamente, interpretada. Conforme Franco (2000) a capacidade de ouvir é fundamental para que o processo de comunicação flua naturalmente. Neste contexto, o diálogo torna-se uma condicionante fundamental para uma boa interação entre o professor e o aluno.

Para Freire (1967) "[...] o diálogo é uma relação horizontal. Nutre-se de amor, humildade, esperança, fé e confiança". Na fala de Freire, percebe-se o vínculo entre o diálogo e o fator afetivo que norteará a virtude primordial do diálogo, o respeito aos educados não somente como receptores, mas enquanto indivíduos. Inadvertidamente, o professor não pode ser autoritário a ponto de achar que sua palavra é a lei, pois, quando há uma falha na comunicação entre professor-aluno e aluno-professor, poderá ocorrer o distanciamento de uma das partes e até de ambas, podendo prejudicar tal relação; uma vez que o diálogo é um elemento fundamental da aprendizagem, fato que é reforçado por Haydt (1995), sobre a importância do estabelecimento do diálogo, esse autor pontua que na relação professor-aluno o diálogo é fundamental. A atitude dialógica no processo ensino-aprendizagem é aquela que parte de uma questão problematizada para desencadear diálogo oportuno, no qual o professor transmite o que sabe, aproveitando seus conhecimentos prévios e as experiências do aluno. Assim, ambos chegam a uma síntese que elucida, explica ou resolve a situação-problema que desencadeou a discussão.

De acordo com Cunha (2001), assim como os professores atuais foram influenciados pela prática pedagógica de professores anteriores, podem, com certeza, influenciar futuros alunos. O professor precisa estar consciente de que, através da prática docente, servirá de modelo, e, muitas vezes, o aluno o tem como modelo sem refletir sobre a própria prática. 
Entende-se, portanto, que ao analisar a real postura do professor quando em sala de aula e comparar esta com a experiência de aprendizagem do aluno, passa-se a compreender que o professor exerce um importante e fundamental papel de mediação, que poderá favorecer ou não ao entendimento e construção do conhecimento tão necessário ao aluno (LEITE, 2006b). Por conseguinte, essa tal postura que deve ser assumida pelo professor inserido no contexto das salas de aula das faculdades e universidades parece afetar diretamente na experiência de aprendizagem de todos os alunos; seja de maneira positiva ou também, de forma negativa.

Como lembra Leite (2006a), "A natureza da experiência afetiva e cognitiva (se prazerosa ou aversiva), nos extremos, depende da qualidade da mediação vivenciada pelo sujeito, na relação com o objeto ", sendo esta favorecida pela história de relação do professor com o objeto de ensino e pelo investimento que o mesmo realiza na mediação entre o aluno e este objeto, através da própria postura que aquele assume em sala de aula.

Por isso, os valores de afetividade e envolvimento, além da clareza nos processos de comunicação e inserção dos alunos ao contexto apresentado se mostram como ferramentas tão poderosas para sucesso dos alunos e compressão das informações a estes repassadas. A aula, portanto, funciona em uma dupla direção: o professor recebe a realidade, trabalha-a cientificamente, e volta a ela de uma forma nova, enriquecida com a ciência e com propostas novas de intervenção. Quando os alunos vivenciam essa dupla direção e percebem que as aulas lhes permitem voltar à realidade pessoal, social e profissional com "mãos cheias" de dados novos e contribuições significativas, esse espaço e ambiente começa a ser um espaço de vida para eles. Tal vivência da realidade, o aprendiz não faz isoladamente, mas sempre "com" outros sujeitos envolvidos (MASETTO, 2003).

Por conseguinte, ao refletir sobre a real função e participação do professor como um profissional inserido no contexto da educação e que este, também, contribui para uma transformação qualitativa da sociedade, há de se considerar a relevância da responsabilidade político-social da docência, haja vista que, as necessidades apresentadas pelos discentes e a interação destes com seus preceptores é completamente responsável pela formação do cidadão e isto perpassa pela dimensão da formação sócio-política, pois esta propicia o ato de se formar cidadãos que serão críticos e que, também, terão seu caráter transformador da realidade que os permeia (DEMO, 2004).

No contexto universitário está posto (inserido/estabelecido) o desafio de um processo contínuo de educação para os estudantes. Contudo, espera-se que os docentes universitários possam contemplar dois polos importantes em suas práticas pedagógicas, a saber: primeiro, considerar o sujeito como sendo histórico e entendê-lo como transformador da sociedade, formado para a cidadania. Segundo, pensando em termos de aprendizagem colaborativa, que se faz necessário que haja uma interrelação e interdependência dos seres humanos, aspectos estes importantes na relação professor-aluno, já que se considera o discente como sujeito também implicado no processo individualizado e coletivo de aprendizagem (BEHRENS, 2000).

Segundo Libâneo (1994) "O professor não apenas transmite uma informação ou faz perguntas, mas também ouve os alunos. Deve dar-Ihes atenção e cuidar para que aprendam a expressar-se, a expor opiniões e dar respostas. $O$ trabalho do docente nunca é unidirecional. As respostas e opiniões mostram como os alunos estão reagindo 
à atuação dos professores e, consequentemente, às dificuldades que encontram na assimilação dos conhecimentos. Servem, também, para diagnosticar as causas raízes que dão origem a essas grandes dificuldades".

Deste modo, conclui-se que tanto o professor quanto o aluno devem ser motivadores mútuos, em suas práticas de interação e aprendizagem em sala de aula, a partir de princípios éticos, que possibilitem que ambos aprendam a ler o mundo com prazer, compromisso e criticamente. A parceria que se estabelece deve aguçar a descoberta autônoma do saber científico, a ruptura com o mundo do senso-comum e a descoberta do saber epistemológico, de modo que seus discursos sejam enunciados a partir de uma voz justa e verdadeira, de libertação e de ruptura com qualquer forma de desigualdade social ou marginalização da pessoa humana (KRONBAUER; SIMIONATO 2008).

Consequentemente, as urgências e as necessidades de aprendizagem dos alunos atuais, sem dúvida, oferecem, também, um grande desafio aos docentes, já que estes são requeridos em grau máximo para se esforçarem na capacitação de seu público alvo, haja vista o elevado nível tecnológico de todas as formas de produção de conhecimento até então existentes. Logo, estar preparado para se enfrentar uma sala de aula exige muita dedicação e esmero na tentativa de se procurar fazer um trabalho pautado na responsabilidade e cuidado, tão necessários para o processo de aprendizado dos alunos (MITTLER, 2003).

Nóvoa (2002) aponta que uma das dimensões da complexidade do ensino é a relação com o educando, pois, diverso do que acontece com outros profissionais "o trabalho do professor depende da colaboração do 'aluno'. [...] Ninguém ensina quem não quer aprender".

A relação professor-aluno é facilitada quando se estabelece a partir da autoridade pedagógica na qual o professor tem consciência de suas limitações e trabalha no sentido de superação da autoridade própria da condição profissional, o que "não significa sua eliminação, uma vez que a intervenção do educador se conserva modificada no raciocínio elaborado pelo aluno, que sente-se respeitado como partícipe do processo de ensino-aprendizagem" (ZUIN, 2008).

É necessário "provocar a "sede" de aprender, problematizando o conteúdo, tornando-o interessante e não tirar o sabor da descoberta dando respostas prontas. Uma das primeiras condições para ser professor é dominar com segurança o conteúdo a ser trabalhado, pois somente assim será possível planejar aulas realmente interessantes, instigantes, que provoquem a turma a buscar respostas (SANTOS, 2008).

A formação e o impacto das relações professor-aluno no ensino superior permanecem inegavelmente sub-representados na literatura, e a perspectiva de um tipo ideal de interação professor-aluno segue altamente variada. Alguns professores e alguns alunos se inclinam para uma hierarquia formal, enquanto outros priorizam a familiaridade e a acessibilidade nos relacionamentos. Com a Geração Z superando os millenials nos ambientes universitários, é provável que o tópico não se torne mais simples. Por fim, é uma área interessante de pesquisa que levanta questões e destaca implicações para o futuro do ensino superior (KENNING, 2019).

Ademais, as relações verticais apresentadas pelos órgãos oficiais educacionais ao propor reformas e novas propostas para o ensino vêm aleijando o professor das discussões e problemáticas próprias de sua função. A profissão docente no Brasil, se 
depara com um processo de desvalorização hipercrítico e com uma massiva perda de sua real identidade. Desta forma a garantia da boa relação entre professores e alunos emerge como uma alternativa de grande impacto para consolidação da formação humana e sustentação do processo de ensino e aprendizagem, pois a integração e envolvimento estre as partes formarão um ambiente científico e propício para que se consiga, também, o sucesso e esmero que se demanda para a formação profissional dos alunos (ALVES; GARCIA, 2000).

\section{CONSIDERAÇÕES FINAIS}

Hoje, já se tem por conhecimento fundamental que no ambiente das faculdades e universidades ocorrem, cotidianamente, múltiplas interações humanas, sendo que a relação existente entre professores e alunos se caracteriza como uma das vertentes de socialização interpessoal mais importante.

Essa mesma relação se faz como pilar significante para a construção do processo de ensino e aprendizagem, uma vez que é por meio de tais participações e convívios que os professores passam a se aproximar e a conhecer melhor seus alunos, podendo assim qualificar o processo de ensino. Em contrapartida, os próprios alunos se sentem mais à vontade para debater e questionar durante as aulas, melhorando, também, esse mesmo processo de aprendizagem. Afinal, no equilíbrio permanente destas interações humanísticas, encontramos o sentido da relação pedagógica. Entretanto, dela também depende a relação do aluno com o conhecimento, com a aprendizagem e, por que não, com todo o contexto geral do que se pressupõe ser 0 ensino universitário.

Desta forma, o professor ambientado na educação superior passa a se tornar um referencial para seus alunos. É necessário, portanto, que o docente se conscientize desta situação, pois, muitas vezes, o educando o segue sem nenhuma reflexão intimista sobre a sua postura de mestre ou, até mesmo de seu papel enquanto indivíduo, o que imprime consequentemente, uma maior responsabilidade à prática do educador. Nesta perspectiva, o professor deve fazer total diferença e contagiar o aluno na busca pelo saber crítico, refletir sistemático e o ato de se analisar dados cientificamente. Pois, observamos que essa relação estabelecida, majoritariamente, nas instituições de educação superior tem possibilitado formas inovadoras de se pensar na organização da ação pedagógica, com um correspondente resultado de uma construção coletiva e participativa do próprio conhecimento.

A partir desta pesquisa, pode-se concluir que a relação professor-aluno, juntamente com a metodologia utilizada pelo professor na dinâmica de execução das aulas são fatores determinantes para o sucesso ou para o infeliz fracasso do aprendizado do aluno. Para tanto, faz-se necessário, que o professor busque a situação social em que seus alunos se encontram, a fim de proporcionar aos mesmos uma aula onde os conteúdos curriculares estejam interdisciplinarmente englobados, e próximos da realidade dos discentes, dando mais ênfase aos contextos em que os mesmos estão inseridos, através de uma comunicação fluida, linear e sem ruídos de forma a aproximar os sujeitos envolvidos, utilizando-se para isto a ferramenta do diálogo.

Adicionalmente, é possível defender que a afetividade também está presente em todas as decisões assumidas pelos professores em sala de aula, produzindo continuamente impactos positivos e, até mesmo, negativos na subjetividade dos alunos. Isto se trata, pois, de um fator fundante nas relações que se estabelecem entre os 
alunos e os conteúdos escolares. O desempenho da mediação pedagógica, portanto, torna-se um dos principais determinantes da qualidade dos vínculos que se estabelecerão entre os sujeitos/alunos e os objetos/conteúdos disciplinares.

Desta forma, podemos afirmar que tanto os professores quanto os alunos admitem que ao adotarem sentimentos de acolhimento e atenção no processo ensinoaprendizagem, bem como ao tomar decisões comprometidas com o desenvolvimento de todos, favorecendo a compreensão, aceitação, comunicação entre as partes e valorização do outro; possibilitam a promoção de uma experiência muito mais positiva para a consecução da aprendizagem. Logo, a participação e atuação de ambos é o que, de fato, justifica a existência desta própria relação. Portanto, compreende-se que tal interação é extremamente importante para o processo geral de ensino, pois, como demonstrado, inúmeras pesquisas atestam a efetividade deste relacionamento para a melhoria e qualificação da aprendizagem dos estudantes dos mais diversos cursos das instituições de educação superior.

Embora, neste trabalho, buscamos compreender a boa relação professor-aluno sistematizada no prisma deste ensino e a influência que este tipo de interação recebe da gestão educacional, é importante destacar que o tema abordado é deveras complexo e envolve muitos outros aspectos não abordados e que, por conseguinte, necessitam de complementação com informações de caráter acadêmico-científico, comportamental e afetivo emocional. As análises e reflexões realizadas constituem subsídios basais, porém importantes para se ampliar a discussão e compreensão de tais interações entre professor aluno no ensino universitário. Sugerimos, portanto, que outras pesquisas sobre o tema sejam instigadas a fim de que se possa contribuir, significativamente, para a melhoria da qualidade do ensino superior brasileiro.

\section{REFERÊNCIAS}

ALVES, N.; GARCIA, R. L. O sentido da escola. 2ª ${ }^{\text {a }}$ Ed. Rio de Janeiro: DP\&A, v. 2 , 2000.

ANASTASIOU, L.; ALVES, L. (Org.). Processos de ensinagem na universidade: pressupostos para as estratégias de trabalho em aula. 3. ed. Joinville: Univille, 2004.

ASSMANN, H. Reencantar a educação: rumo à sociedade aprendente. Petrópolis, RJ: Vozes, 2007.

BEHRENS, M. A. Novas Tecnologias e mediação pedagógica. Campinas, SP: Papirus, 2000.

BORDENAVE, J. D. O que é comunicação. SP: Brasiliense, 2006.

BUBER, M. Eu e tu. 10 ed. São Paulo: Centauro, 2006.

BROUSSEAU, G. Théorie des Situations Didactiques: Didactique des Mathématiques. Grenoble: La Pensée sauvage, 1998. 
BRASIL. (LDB), Lei n.o 9.394/96, de 20 de dezembro de 1996. Estabelece as diretrizes e bases da educação nacional. Disponível em: <http://www.camara.gov.br/sileg/integras/152182.pdf>.

CAPITANIO, A. M. Relacionamento não verbal na Educação Física. Efdeportes: revista digital, Buenos Aires, 2003.

COSSO, E.; FRANCO, M. L. P. B.; FERNANDES, J. S. G. Representações sociais sobre relação professor-aluno no ensino superior. Revista Brasileira de Ensino Superior, v. 4, n. 3, p. 5-23, 2018. Disponível em: < https://seer.imed.edu.br/index.php/REBES/article/view/2389>.

CUNHA, M. I. O Bom Professor e a sua Prática. 12. ed. Campinas: Papirus, 2001.

CUNHA, M. I. O bom professor e sua prática. 2 ed. São Paulo: Papirus, 2006.

DEMO, P. Revista Profissão Mestre. Curitiba, Paraná, ano 6. n 61. p. 18- 26, 2004.

FRANCO, G. S. Psicologia no esporte e na atividade física: uma coletânea sobre a prática com qualidade. São Paulo: Manole, 2000.

FREIRE, P. Pedagogia do oprimido. São Paulo, 2005.

FREIRE, P. Educação como prática de liberdade. Rio de Janeiro: Paz e Terra, 1967.

FURLANI, L. M. T. A parceria e a aproximação na relação professor - aluno na universidade. Em L. R. Almeida \& V. M. N. S. Placco (Org.), As relações interpessoais na formação de professores (pp. 51-64). São Paulo: Loyola, 2004.

GIL, A. C. Como elaborar projeto de pesquisa. São Paulo: Atlas, 2008.

GÓMEZ, A. I. P. A aprendizagem escolar: da didática operatória à reconstrução da cultura na sala de aula. In: SACRISTÁN, J. G.; PÉREZ GÓMEZ, A. I. Compreender e transformar o ensino. 4.ed. Porto Alegre: Artmed, 2000.

HAYDT, R.C. Curso de didática geral. 2a ed. São Paulo: Ática, 1995.

JUSVIACK, A. Focos e enfoques da indisciplina. 2008.

KENNING, M. A. From Learner to Leader: A Reflective Analysis of the Teacher-Student Relationship. Journal of Leadership Studies, v. 13, n. 2, p. 64-67, 2019. Disponível em: < https://doi.org/10.1002/jls.21646>.

KRONBAUER, S. C. G; SIMIONATO, M. F. (Org.). Formação de professores: abordagens contemporâneas. São Paulo: Paulinas, 2008. 
LEITE, S. A. S. Dimensões afetivas na relação professor aluno In: TASSONI, E. C. M. A afetividade em sala de aula: as condições de ensino e a mediação do professor. São Paulo: Casa do psicólogo, 2006a.

LEITE, S. A. S. Afetividade e práticas pedagógicas. São Paulo: Casa do psicólogo, $2006 \mathrm{~b}$.

LIBÂNEO, J. C. Didática. São Paulo: Cortez Editora, 1994.

LIBÂNEO, J. C. Pedagogia e Pedagogos, para quê? São Paulo: Cortez, 1998.

MASETTO, M. T. (2003). Competência pedagógica do professor universitário. São Paulo: Summus, Editorial.

MEIRELES, D.S.L; MEIRELES, R.F.TAHIM, A.P.V.O; CARNEIRO, S.N.V. A teoria do agir comunicativo e sua contribuição para a relação professor-aluno no ensino superior. Revista Docência do Ensino Superior, v. 7, n. 2, p. 97-112, 2017. Disponível em: < https://periodicos.ufmg.br/index.php/rdes/article/view/2349>.

MITTLER, P. Educação inclusiva: contextos sociais. Porto Alegre: ArtMed, 2003.

NÓVOA, A. A Formação de professores e trabalho pedagógico. Lisboa: Educa, 2002.

PIAGET, J. Psicologia e Pedagogia. Rio de Janeiro: Forense: Universitária, 1992.

PIMENTA, S G; ANASTASIOU, L. G. C. Docência no Ensino Superior. 4 ed. São Paulo: Cortez, 2010.

POPKEWITZ, T. Lutando em defesa da alma: a política do ensino e a construção do professor. Porto Alegre: Artmed, 2001.

SANTOS, S. C. O processo de ensino-aprendizagem e a relação professor-aluno: Aplicação dos "sete princípios para a boa prática na educação do ensino superior". Caderno de Pesquisa em Administração. São Paulo, v. 08, ํo 1, janeiro/março. 2001. Disponível em: <http://regeusp.com.br/arquivos/v08-1art07.pdf>

SANTOS, S. C. Aprendizagem Significativa: modalidades de aprendizagem e o papel do professor. Porto Alegre: Mediação, 2008.

SILVA, A. R. C. Sentimentos e emoções: um estudo com professores e alunos de medicina veterinária. Tese (Doutorado) - PUC, São Paulo, 2005.

SILVA, M. S. Um pensar sobre a ética nas relações docentes e aluno no Ensino Superior. Revista Estação Científica, n. 11, p. 1-6, jan./jun. 2014. Disponível em: <http://portal.estacio.br/media/4446/artigo-01-mariana-si-queira-silva.pdf>. 
SILVA, S. L. A Dimensão da afetividade na relação professor/aluno. Humanidades \& Inovação, v. 6, n. 2, p. 168-175, 2019. Disponível em: < https://revista.unitins.br/index.php/humanidadeseinovacao/article/view/1029>.

TAVARES, J. Uma Sociedade que Aprende e se desenvolve: Relações Interpessoais. Porto: Porto, 1996.

VYGOTSKI, L. S. Obras Escogidas V - Fundamentos de defectología. Madrid: Visor Dis., 1997.

ZUIN, A. Adoro odiar meu professor: o aluno entre a ironia e o sarcasmo pedagógico. Campinas: Autores Associados, 2008. 